\title{
Penguatan usaha kelompok budidaya ikan tawar "Mujur Fish Farm" dimasa pandemi Covid-19 dengan membangun mindset and spirit entrepreneur
}

\section{Bahri*, Widodo Prastyo, \& Dicky Dicky Arnendra Dwi Nugraha}

Fakultas Ekonomi, Universitas Widya Mataram, Indonesia

* bahri@widyamataram.ac.id

\begin{abstract}
The rapid spread of Covid-19 in Indonesia led the government to impose physical distancing and Large-Scale Social Restrictions (PSBB) resulting in declining sales activity. One of the business groups affected by Covid-19 is the Fish Farming Group "Mujur Fish Farm". This devotion aims to foster the mindset and spirit of entrepreneurs, as well as increase knowledge related to the right steps so that products can be sold. The implementation method uses Participatory Rural Appraisal (PRA) by involving the local community. The stage of implementation is through the stage of preparation, planning, implementation and evaluation, and assessment stages. The achievement of this activity is that group members know how to build an entrepreneur mindset in the Covid-19 pandemic by staying positive and creative. The rapid spread of Covid-19 in Indonesia led the government to impose physical distancing and Large-Scale Social Restrictions (PSBB) resulting in declining sales activity. One of the business groups affected by Covid-19 is the Fish Farming Group "Mujur Fish Farm". This devotion aims to foster the mindset and spirit of entrepreneurs, as well as increase knowledge related to the right steps so that products can be sold. The implementation method uses Participatory Rural Appraisal (PRA) by involving the local community. The stage of implementation is through the stage of preparation, planning, implementation and evaluation, and assessment stages. The achievement of this activity is that group members know how to build an entrepreneur mindset in the Covid-19 pandemic by staying positive and creative.
\end{abstract}

Abstrak Penyebaran Covid-19 di Indonesia yang begitu cepat membuat pemerintah memberlakukan physical distancing dan Pembatasan Sosial Berskala Besar (PSBB) mengakibatkan aktivitas penjualan mengalami penurunan. Salah satu kelompok usaha yang terkena dampak Covid-19 adalah Kelompok Budidaya Ikan "Mujur Fish Farm". Pengabdian ini bertujuan untuk menumbuhkan mindset and spirit entrepreneur, serta meningkatkan pengetahuan terkait langkah tepat agar produk bisa laku terjual. Metode pelaksanaan menggunakan Participatory Rural Appraisal (PRA) dengan melibatkan masyarakat setempat. Tahapan pelaksanaannya melalui tahap persiapan, perencanaan, pelaksanaan dan tahap evaluasi dan penilaian. Adapun capaian dari kegiatan ini adalah anggota kelompok mengetahui cara membangun mindset entrepreneur dimasa pandemi Covid-19 dengan tetap berpikir positif dan kreatif. Melakukan evolusi produk dengan mengubah ikan menjadi produk Dimsum. Hasil pengabdian ini mampu meningkatkan mindset and spirit berwirausaha anggota kelompok dari $40 \%$ meningkat menjadi 93\%. Meningkatkan kemauan anggota kelompok untuk melakukan penjualan secara online melalui aplikasi WhattsApp, Facebook, Instagram ataupun melalui aplikasi E-Commerce

\section{¿ OPEN ACCESS}

Citation: Bahri., W. Prastyo., \& D. D. A. Dwi Nugraha. (2021). Penguatan usaha kelompok budidaya ikan tawar "Mujur Fish Farm" dimasa pandemi Covid-19 dengan membangun mindset and spirit entrepreneur. Riau Journal of Empowerment, 4(3), 149-163.

https://doi.org/10.31258/raje.4.3.149-163

Received: 2021-08-09 Revised: 2021-12-27 Accepted: 2021-12-28

Language: Bahasa Indonesia (id)

Funding: LPPM Universitas Widya Mataram, Indonesia

ISSN 2623-1549 (online), 2654-4520 (print)

C 2021 Bahri, Widodo Prastyo, \& Dicky Dicky Arnendra Dwi Nugraha. Author(s) retain the copyright of article published in this journal, with first publication rights granted to Riau Journal of Empowerment. The article is licenced under Creative Commons Attribution 4.0 International License. This license permits unrestricted use, distribution, and reproduction in any medium, provided the original author and source are credited. 
150

terbukti sebesar 7,58\% yang awalnya hanya $1,7 \%$. Meningkatnya pendapatan sebesar $60 \%$ yang awalnya tidak ada penjualan dan pendapatan sama sekali dimasa pandemi Covid-19. Berhasilnya anggota kelompok membuka usaha baru yaitu kolam pemancingan berbayar.

Keywords: mindset; entrepreneurial spirit; product innovation; Covid-19 
Laju penularan Covid-19 di Indonesia belum bisa dikendalikan pemerintah sampai saat ini, walaupun pemerintah telah mengambil langkah cepat dengan melakukan pengadaan vaksin Covid-19 untuk memberikan kekebalan tubuh di lingkungan masyarakat. Namun dikutip dari (Fitra, 2021) Kemenkes RI menyampaikan sampai bulan Juli 2021 ada penambahan 38.679 kasus baru Covid-19 di Indonesia sehingga sejak Maret 2020 hingga saat ini berjumlah 3.166.505 kasus. Selain pemberian vaksin, pemerintah Indonesia juga memberlakukan Pembatasan Sosial Berskala Besar yang tertuang dalam Peraturan Pemeritah No. 21/2020 yang dampaknya membuat aktivitas ekonomi dan perdagangan di Indonesia menjadi lesu. Terbukti dari hasil (Badan Pusat Statistik, 2020) dimana pada triwulan II 2020, pertumbuhan ekonomi Indonesia mengalami kontraksi sebesar $-5,32$ persen yang membuat perekonomian Indonesia berada pada zona krisis (Maria E, et al., 2021).

Dengan penerapan physical distancing dan pembatasan sosial berskala besar mengantam seluruh aktivitas perdagangan baik di kota, desa, dan antar pulau di seluruh pelosok negeri ini. Tak hanya pedagang besar, Usaha Mikro Kecil dan Menengah (UMKM) bahkan petani pun mengalami penurunan penjualan dan pendapatan terutama perdagangan yang masih mengandalkan toko fisik dan penjualan langsung (Maria E, et al., 2021). Adapun dampak penyebaran Covid-19 di Indonesai pelaku UMKM mengalami penurunan pendapatan sebesar $41,91 \%$, karyawan yang dirumahkan sebesar $60,74 \%$. Adapun perusahaan-perusahaan yang sementara berhenti beroperasi tertinggi ialah jasa pendidikan, $95,21 \%$, real estate $92,86 \%$, jasa perusahaan 93,59\%, transportasi dan pergudangan 92,20\%, keuangan dan asuransi 90,24\% serta jasa lainnya $93,55 \%$.

Menurut (Neneh, 2012) salah satu cara pelaku wirausaha untuk memperkuat dan mempertahankan usahanya disaat mengalami krisis ialah dengan mulai mengubah mindset atau pola pikir. Pelaku wirausaha harus berpikir mencari terobosan peluang-peluang usaha baru yang kreatif, inovatif dan peluang yang mengarah pada penciptaan dan kesuksesan kekayaan. Hasil penelitian (Lewenussa \& Suaidy, 2019) membuktikan bahwa mindset kewirausahaan berpengaruh positif dan signifikan terhadap motivasi dan keterampilan berwirausaha. Maknanya mambangun mindset entrepreneur dapat menjadi strategi yang baik dalam berwirausaha. Selanjutnya (Dewi, 2018) menjelaskan mindset positif merupakan semangat pantang menyerah, mau belajar sesuatu yang berbeda dan berani mengambil resiko.

Selain pola pikir, menurut (Hendro, 2011) spirit entrepreneur dapat menjadi mendorong para pelaku bisnis dalam menghadapi perubahan dan krisis ekonomi. Hendro menambahkan spirit entrepreneur yang perlu dilakukan disaat mengalami krisis ialah dengan melakukan evolusi produk, evolusi ilmu pengetahuan, perubahan gaya hidup, selera dan hobi, perubahan teknologi, dan perubahan budaya. Diperkuat dengan hasil penelitian (Purwaningsih, 2015) yang mengungkapkan spirit entrepreneur berpengaruh positif terhadap minat berwirausaha.

Kelompok Budidaya Ikan Tawar "Mujur Fish Farm" merupakan kelompok penggerak pemberdayaan dan kesejahteraan keluarga dalam bentuk pembudidayaan ikan tawar. Kelompok ini terbentuk tanggal 25 Agustus 2019 di Brengosan Desa Donoharjo, Nganglik, Sleman, Yogyakarta dengan anggota sebanyak 15 orang. Namun kondisi dan situasi pandemi Covid-19 ini membuat kegusaran terhadap keberlangsungan hidup usaha yang di jalankan oleh Kelompok Tani Budidaya Ikan Tawar "Mujur Fish Farm" yang dampaknya sangat dirasakan oleh anggota kelompok. Hasil wawancara dengan ketua kelompok ditemukan permasalahan dimana sejak adanya pandemi Covid-19 jumlah penjualan mengalami penurunan. Sebelum 
pandemi covid-19 sehari ikan bisa terjual sampai 20-30 kilo, tetapi saat ini hanya bisa terjual 5 kilo sehari, itupun bisa kurang. Penjualan ikan selama ini dijual langsung ke pasar dan pelaku usaha rumah makan, namun saat ini banyak rumah makan yang tutup dan tidak jualan akibat pengunjung rumah makan menurun, terutama setelah diberlakukannya PSBB dan PPKM banyak tempat wisata tutup. (Subargah, 2021) menyampaikan pariwisata di desa di kawasan Kaliurang pun tutup, seperti Studio Alam Gamplong, Obelix Hill, Taman Wisata Candi Ratu Boko dan Candi Prambanan, dll. Dari data Dinas Pariwisata Kota Yogyakarta, terdapat sekitar 19 destinasi wisata dan 15 di antaranya memutuskan untuk tutup sementara saat pandemi Covid-19. Akibat menurunnya penjualan berdampak pada spirit atau semangat anggota kelompok "Mujur Fish Farm" untuk mengembangkan usaha kolam ikannya mengalami kemunduruan.

Masalah ini harus segera dibenahi, anggota kelompok "Mujur Fish Farm" harus bangkit. Sehingga Tim Pengabdian Kepada Masyarakat perlu memberikan materi terkait strategi membangun mindset and spirit dalam membangun usaha, agar anggota kelompok tetap produktif dan mendapatkan penghasilan Masyarakat Dusun Brengosan, Donoharjo harus mulai berinovasi, tidak hanya menjual langsung ikan mentah, namun harus bisa mengolahnya menjadi produk yang layak untuk dijual. Selain itu mengubah strategi penjualan dari tatap muka menjadi digital atau online. Anggota kelompok harus tetap memiliki spirit dengan menciptakan alternatif usaha sesuai situasi, harus lebih berinovasi, harus menemukan strategi progresif agar dapat bertahan dengan situasi apapun. Modal positif dimana dari hasil observasi awal tim penyuluh, kami melihat adanya ke kompakan dari anggota kelompok "Mujur Fish Farm" untuk mau bangkit dan maju bersama dan mendorong partisipasi petani untuk meningkatkan produktifitasnya.

Berangkat dari permasalahan diatas, adapun tujuan dari pengabdian kepada masyarakat ini adalah: Pertama, memberikan strategi yang tepat untuk membangun mindset entrepreneur pada anggota kelompok budidaya ikan tawar "Mujur Fish Farm" agar mampu mengolah ikan menjadi produk yang dibutuhkan dan laku terjual diaat pandemi Covid-19. Kedua, membangun sipirit entrepreneur pada anggota kelompok budidaya ikan tawar "Mujur Fish Farm" agar terus bersemangat menjalankan usahanya dimasa pandemi Covid-19. Ketiga, Memberikan langkah-langkah tepat yang harus dilakukan anggota kelompok budidaya ikan tawar "Mujur Fish Farm" agar produknya bisa laku terjual dimasa pandemi Covid-19, sehingga tetap mempunyai pendapatan.

\section{METODE PENERAPAN}

Program Pengabdian Kepada Masyarakat ini merupakan hasil tindaklanjut kerjasama antara Program Studi Kewirausahaan Fakultas Ekonomi Universitas Widya Mataram dengan Kelompok Budidaya Ikan Tawar "Mujur Fish Farm" di Dusun Brengosan Brengosan Desa Donoharjo, Kecamatan Nganglik, Kabupaten Sleman, Kota Yogyakarta. Metode penerapan dalam kegiatan Pengabdian Kepada masyarakat (PkM) ialah menggunakan Participatory Rural Appraisal (PRA) dengan menekankan pada keterlibatan kelompok masyarakat dalam meningkatkan kemampuan potensi dan pengetahuan lokal dalam mengatasi permasalahan wilayahnya (Tambajong, 2015). Kelompok masyarakat membuat penilaian, membuat analisa permasalahan. Setelah itu menyampaikan permasalahannya dan berkerjasama dengan tim pengabdian untuk merencanakan dan membuat program sesuai dengan kondisi dan permasalahannya. Dalam kegiatan ini partisipasi, masukan, evaluasi dan kerjasama dari masyarakat sangat bernilai penting. 
Dalam pelaksanaan pengabdian kali ini sangat berbeda dengan mengikuti intruksi pemerintah yang melarang adanya kegiatan berkumpul (social distancing). Adapun kegiatan pelaksanaan kegiatan pengabdian untuk masing-masing program dalam memecahkan permasalahan adalah sebagai berikut:

\section{Tahap Persiapan}

Dalam tahap ini dosen dan mahasiswa prodi kewirausahaan melakukan company visit dengan kunjungan ke lokasi pembudidaya Ikan Tawar "Mujur Fish Farm" untuk melihat keadaan lokasi penyuluhan. Adapun keadaan saat survey lokasi budidaya ikan tawar dapat dilihat pada Gambar 1.
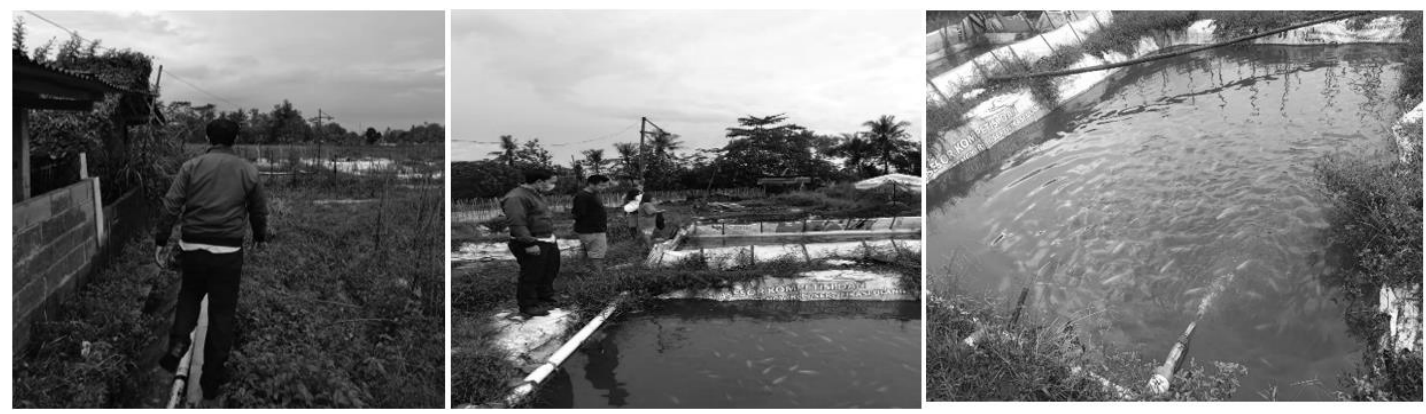

Gambar 1. Survey lokasi dan tempat budi daya ikan tawar kelompok Mujur Fish Farm

Dari hasil pertemuan dengan ketua kelompok "Mujur Fish Farm", ditetapkan pelaksanaan pengabdian pada hari Senin, 28 Juni 2021 bertempat di Rumah Angger Gigih Wiratmoko selaku ketua kelompok dengan tetap mengikuti protokol kesehatan. Setelah tim melakukan mempersiapkan kebutuhan yang menunjang pelaksanaan pengabdian termasuk pembuatan materi.

\section{Tahap Pelaksanaan}

Metode yang digunakan dalam kegiatan Pengabdian Kepada Masyarakat ini adalah metode ceramah dan melakukan post test terkait tingat mindset dan spirit dari setiap anggota kelompok dengan memberikan kuesioner. Selanjutnya setelah pemberian materi dilakukan kembali evaluasi untuk melihat ada atau tidaknya peningkatan mindset dan spirit anggota kelompok untuk kembali bangkit mengembangkan usaha budi daya ikan tawarnya selama pandemi-19. Adapun langkah-langkah yang dilakukan dalam kegiatan ini diuraikan sebagai beriku

\section{Langkah 1. Post Test}

Dalam tahap ini diawali ketua tim penyuluh memberikan pertanyaan dengan cara membagikan kuesioner kepada peserta dalam hal ini anggota kelompok yang item pertanyannya terkait: a) masih semangat untuk mengembangkan usaha ikan atau berhenti; b) bagaimana cara anggota kelompok melakukan penjualan ikan selama covid-19, apakah secara online atau masih manual dengan menyerahkan langsung ke pengepul atau penjual pecel lele; c) kendala-kendala apa saja yang dihadapi selama covid-19. Adapun hasil post test nya sebagai berikut: 


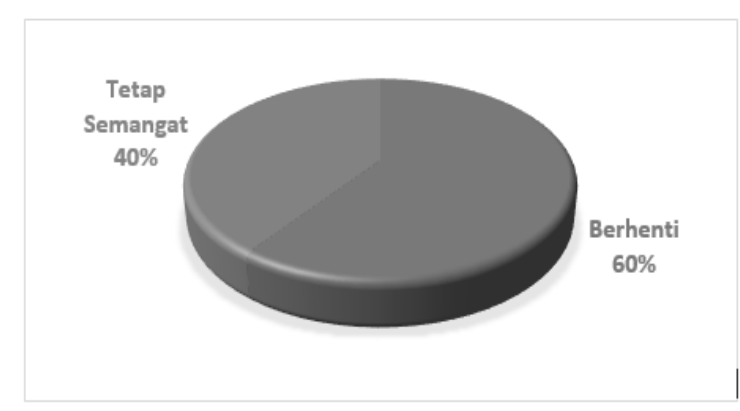

Gambar 2. Hasil Pre-Test Tentang Besaran Mindset dan Spirit Anggota Kelompok

Dari hasil jawaban kuesioner pre-test awal 60\% anggota kelompok "Mujur Fish Farm" sudah mau berhenti membudidayakan ikan tawar, dengan alasan dampak dari Covid-19 menyebabkan pesanan ikan menurun dan pendapatan juga ikut menurun, sedangkan kebutuhan hidup rumah tangga tetap tinggi, sehingga mereka ingin mencara pekerjaan lain saja. Sedangkan $40 \%$ anggota kelompok jawabannya masih tetap semangat (spirit) dan tetap mempunyai pola pikir (mindset) positif untuk terus berjuang mengembangkan usaha budidaya ikan tawar, dan membutuhkan butuh ide-ide pemasaran dan model usaha yang baru untuk lebih menarik minat pembeli.

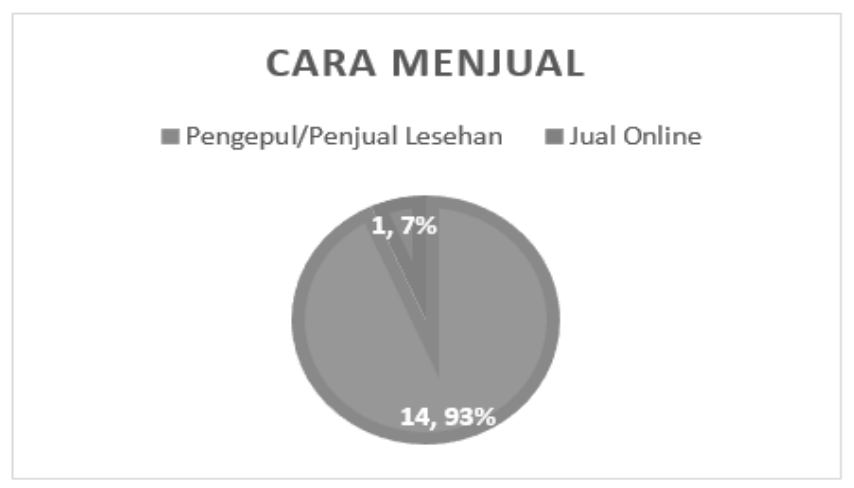

Gambar 3. Hasil Pre-Test Tentang Cara Penjualan Hasil Budi Daya Ikan

Berdasarkan hasil jawaban diatas, selama ini anggota kelompok "Mujur Fish Farm", melakukan penjualan dengan cara dimana pengepul langsung datang ke anggota kelompok untuk membelinya dengan cara sistem borongan saat panen, hanya ketua kelompok yang sering menawarkan ikan ke konsumen secara online melalui WhasApp. Selain itu juga anggota kelompok bekerja sama dengan pelaku usaha rumah makan dan penjual pecel lele, sehingga sebelum pandemi berlangsung mereka diminta untuk mensuplai ikan lele, bawal dan nila. Namun masalahnya setelah pemerintah memberlakukan PPKM menyebabkan rumah makan dan warung pecel lele tutup, sehingga tidak ada lagi pemesanan dan pengantaran ikan. 


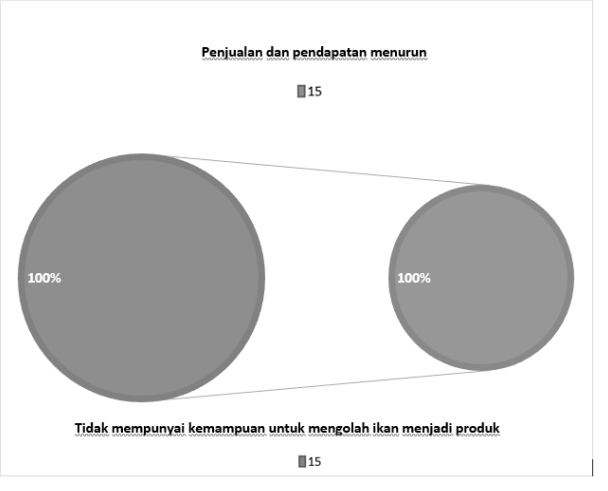

Bahri et al.

Gambar 4. Hasil Pre-Test Tentang Kendala-Kendala Anggota Kelompok Selama Covid-19

Dari hasil gambar diatas menunjukkan semua anggota kelompok "Mujur Fish Farm", menyampaikan imbas dari berlakunya aturan pemerintah terkait PPKM menyebabkan rumah makan yang sudah ada kerjasama berhenti beroperasi dan tidak melakukan penjualan kembali, akibatnya penjualan menurun dan efeknya pendapatan dari setiap kelompok ikut mengalami penurunan juga. Dengan tidak adanya suplai ikan ke rumah makan, menyebabkan stok ikan di kolam banyak, namun anggota kelompok ikan kebingungan untuk mengubah ikan menjadi produk yang layak jual. Apalagi anggota kelompok ini semua berjenis kelamin laki-laki yang sudah berumur, sehingga mindset mereka untuk melakukan ide-ide inovasi mengubah ikan menjadi produk lain yang layak untuk di jual susah dilaksanakan.

Langkah 2. Metode Ceramah (Penyampaian Materi)

Setelah uji post test dilakukan, tahap pelaksanaan penyuluhan selanjutnya ketua kelompok memberikan materi dengan metode ceramah terkait tata cara membangun mindset and spirit entrepreneur pada anggota kelompok budidaya ikan tawar "Mujur Fish Farm" dimasa pandemi Covid-19. Dilanjutkan dengan pemutaran video tentang peningkatan pola pikir dan semangat berwirausaha. Setelah itu memberi materi tentang langkah-langkah tepat yang perlu dilakukan anggota kelompok "Mujur Fish Farm" agar bisa bertahan dan materi terakhir strategi penjualan produk biar bisa bisa laku terjual dimasa pandemi Covid-19. Pemateri kedua anggota kelompok memaparkan materi terkait cara melakukan penjualan secara online dengan memanfaatkan WhattsApp dan aplikasi e-commerce. Selain itu juga anggota kelompok diberikan materi terkait cara mengubah ikan menjadi produk lain yang layak jual seperti mengubah ikan menjadi krupuk dan Dimsum Siomay.

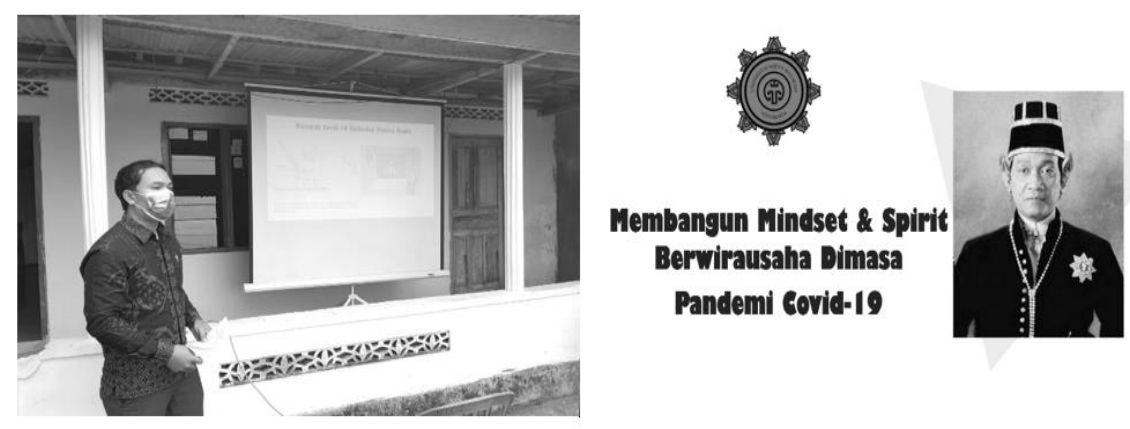

Gambar 5. Penyampaian Materi Penyuluhan

\section{Tujuan Pelaksanaan}

Tujuan utama metode Pre-Test ini untuk mengetahui sejauhmana para peserta memahami materi yang akan disampaikan, dan untuk mengetahui apa saja langkah-langkah yang sudah 
dilakukan untuk menghadapi pandemi Covid-19 agar usahanya tetap berjalan. Sedangkan metode ceramah dilakukan dengan tujuan memberikan pengetahuan kepada setiap anggota agar kembali bangkit dalam meningkatkan dan mengembangkan kembali budi daya ikan lele nya dan juga dari materi ini mereka bias mendapatkan ide dan inovasi dalam mengubah ikan menjadi produk lain yang mempunyai nilai jual tinggi seperti dimsum.

Langkah 3. Tahap Evaluasi dan Penilaian

Untuk mengukur tingkat ketercapaian kegiatan penyuluhan tentang cara mereka membangun pola pikir (mindset) dan semangat (spirit) dimasa pandemi Covid-19. Langkah-langkah untuk bisa mempertahankan usaha budidaya ikan tawar dimasa pandemi Covid-19 pada kelompok "Mujur Fish Farm". Untuk lebih memperdalam kembali pemahaman peserta, diakhir presentasi kami memberi kesempatan kembali kepada peserta untuk memberikan pertanyaan dan mendiskusikan kembali letak ketidakpengetahuan peserta, mendiskusikan permsalahanpermasalahan yang selama ini mereka alami, setelah itu tim penyuluh memberikan jawaban atas pertanyaan tersebut dan memberikan solusi atas permasalahan yang dialami oleh peserta. Tujuannya untuk menganalisis dan mengukur tingkat perubahan pengetahuan peserta pra dan pasca penyuluhan terkait pola pikir dan semangatnya dalam melanjutkan usahanya. Selain itu, melihat strategi terbaru apa yang sudah terpikirkan para peserta agar usahanya tetap berjalan dan produk yang dijual bisa laku dipasar selama pandemi Covid-19 berjalan dengan menggunakan metode analisis kualitatif. Metode penilaian kualitatif dari tim penyuluh sesuai target luaran dari kegiatan pengabdian ini dimana anggota kelompok dapat membuat rancangan dan gambaran program-program ataupun strategi yang dapat membangun kembali semangat mereka untuk bangkit kembali dan usahanya tetap berjalan disaat pandemi Covid19. Setelah dilakukan diskusi dan tanya jawab.

\section{HASIL DAN KETERCAPAIAN SASARAN}

Di masa pandemi Covid-19 saat ini, banyak karyawan yang terkena dampak pemberhentian karyawan (PHK) sehingga pendapatan menurun yang dampaknya daya beli masyarakat menurun, dan imbasnya pada pelaku usaha yang pemesanan dan pendapatan juga ikut mengalami penurunan, efeknya banyak pelaku usaha yang bangkrut dan tutup. Berdasarkan yang tercantum dalam Buku Laporan Ketenagakerjaan Dalam Data (2021) dilaporkan Pengangguran Terbuka Karena Covid-19 berdasarkan Provinsi total sebanyak 2.562.530 orang dengan sebaran berada provinsi Jawa Barat sebanyak 697.196 orang atau sebesar 27,21 persen, provinsi Jawa Tengah berada di urutan kedua dengan jumlah penganggur sebanyak 377.199 orang atau sebesar 14,72 persen, provinsi Jawa Timur dengan jumlah penganggur sebanyak 318.609 orang atau sebesar 12,43 persen yang juga didominasi. Sedangkan Daerah Istiewa Yogyakarta jumlah pengangguran akibat Covid-19 sebanyak 32,371 orang (Wirawan, 2021). Adapun rinciannya sebagai berikut: 


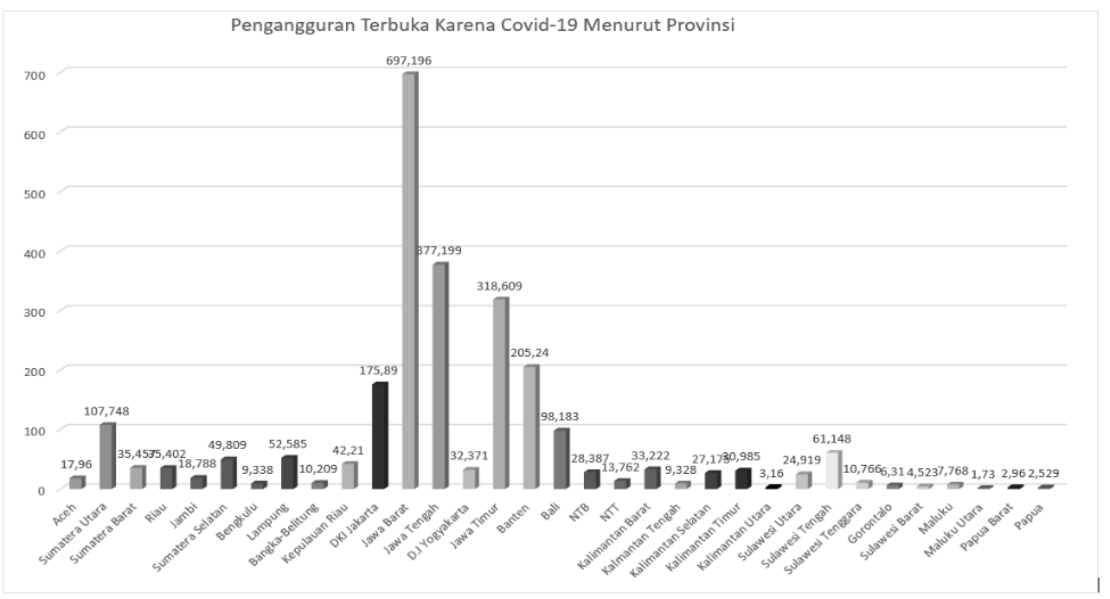

Sumber: Laporan Ketenagakerjaan, 2021

Gambar. 6 Pengangguran Terbuka Berdasarkan Wilayah

Pola pikir (mindset) merupakan keseluruhan dimiliki yang berhubungan dengan harapan, keyakinan, sikap, kebiasaan, keputusan dan pendapat yang kita keluarkan dalam memandang diri kita sendiri. Mindset adalah cara berpikir atau kepercayaan yang menentukan perilaku, sikap, dan pandangan akan masa depan seseorang (Gunawan, 2007). Kekuatan pola pikir (mindset) dapat mengubah aspek psikologis, dan akhirnya mengubah hidup seseorang bahwa kesuksesan tidak hanya dipengaruhi oleh kemampuan dan bakat, tetapi juga oleh pola pikir (Dweck, 2006). Dweck (2006) menambahkan adapun mindset dalam diri seseorang ada dua macam. Pertama, fixed mindset dimana seseorang percaya bahwa kemampuan untuk melakukan sesuatu dipengaruhi oleh faktor genetis atau bawaan. Ciri-ciri seseorang yang fixed mindset yaitu pola pikir yang statis, mudah menyerah, selalu melihat sisi negatif dalam dirinya dan melihat kegagalan sebagai akhir segalanya. Kedua, growth mindset dimana pola pikir yang dapat dikembangkan dengan bekerja keras, meningkatkan keterampilan dan keahlian. Ciri-ciri seseorang yang mempunyai growth mindset yaitu pola pikir berkembang, tidak mudah menyerah, lebih cenderung berpikir positif, kemampuan bisa dikembangkan dan selalu bangkit saat ada musibah atau kegagalan. Adapun cara untuk membangun mindset entrepreneur dimasa pandemi Covid-19 adalah:

\section{Berpikir positif dan kreatif}

Berpikir kreatif disini perlu melakukan sesuatu untuk menghasilkan cara atau hasil baru dari sesuatu yang telah dimiliki berupa gagasan maupun karya nyata yang relatif berbeda dengan apa yang telah ada (Euis, 2010). Anggota kelompok "Mujur Fish Farm" dalam menghadapi musibah Covid-19 ini dengan berpikir positif. Dengan berpikir positif maka bermanfaat untuk a) memudahkan dalam pengambilan keputusan (decision making), b) memberi kemudahan dalam pemecahan masalah (problem solving) dengan mampu identifikasi masalah, memahami situasi dan mencari jawaban dan kesimpulan, dan c) mampu menciptakan gagasan baru (create ideas) yang bersifat orisinal dengan berpikir divergen, yaitu menghasilkan sejumlah ide alternatif sebagai pilihan.

2. Bertanggung jawab dan berani mengambil risiko

Ketekunan dan penuh tanggung jawab menjadi penentu keberhasilan seorang dalam mengelola segala kegiatan yang dilakukan dalam bidang usahanya (Latief, 2017). Setiap anggota kelompok "Mujur Fish Farm" harus bertanggung jawab terhadap segala aspek yang terkait kemajuan usahanya, terutama ketua kelompoknya harus bertanggung jawab pada kemajuan 
usaha dan kesejahterahan timnya. Selain itu, untuk menghadapi pandemi Covid-19 ini anggota kelompok harus berani mengambil risiko dari segi waktu dan biaya agar usahanya tetap terus berjalan, siap menghadapi perubahan budaya pembelian konsumen, harus berinovasi pembuatan produk baru yang berbeda, berinovasi dalam strategi penjualan secara digital, dan harus mempunyai ide-ide kreatif dan menarik konsumen untuk datang membeli. Namun perlu diingat, dalam pengambilan risiko harus melalui pemikiran matang, analisis, perhitungan serta pertimbangan yang jelas.

\section{Percaya diri}

Sikap percaya diri disini mengandung nilai-nilai keyakinanan, optimisme serta keyakinan untuk mencapai keberhasilan. Anggota kelompok "Mujur Fish Farm” dimasa pandemi Covid19 jangan sampai kehilangn percaya diri, karena dalam bersaing dan memajukan usaha yang sedang dijalankan membutuhkan sikap dan mentalitas yang kuat. Selain itu rasa percaya diri mempunyai dampak pada a) keberhasilan usaha, b) mampu mempengaruhi sikap mental, gagasan, kreatifitas, keberanian dan semangat kerja tim, dan untuk bisa menghasilkan karya terbaik.

\section{Mampu kendalikan emosi}

Emosi bisa berdampak positif atapun negatif bagi pelaku bisnis. Emosi dalam kesuksesan berwirausaha adalah antusiasme. Dengan adanya emosi memberikan gairah dalam menjalan usaha. Emosi yang positif membuat pelaku usaha memiliki nyali serta keberanian untuk membangun bisnis, berani bersaing dengan pelaku usaha yang lain.

Materi utama yang selanjutnya membahas cara membangun spirit entrepreneur anggota kelompok budidaya ikan tawar "Mujur Fish Farm" di Masa Pandemi Covid-19 yang dapat dilakukan melalui 1) Tekad dan niat dalam membangun usaha, 2) Jeli dalam melihat peluang usaha, 3) Mau belajar dari orang lain, dan perlu menetapkan modal usaha yang terdiri dari modal investasi awal (modal membangun atau sewa bangunan, membeli peralatan), modal kerja (modal pembelian bahan baku produk) dan modal operasional (pemeliharaan, gaji, pembayaran pajakm dll), 4) Memiliki kemampuan menjual yang bersifat (mampu berkomunikasi, penuh inisiatif, berpikir kreatif, penuh perhatian, tidak mudah putus asa, menarik, mudah bergaul, dan selalu gembira, memilik sopan santun, lurus hati, dan disiplin, serta kuat dalam daya ingat). Cara menjaga mentalitas dan spirit entrepreneur dalam menjaga usaha untuk tetap survive adalah sebagai berikut (Apriansyah, et al., 2020): 
Tabel 4.1 Sukses vs Gagal Dalam Menjaga Mentalitas dan Spirit

\begin{tabular}{|c|c|}
\hline Sukses & Gagal \\
\hline Banyak mencari referensi & Malas \\
\hline Mampu mengimplementasikan ide/kreativitas & $\begin{array}{l}\text { Tidak mampu } \\
\text { mengimplementasikan ide }\end{array}$ \\
\hline Menjaga kesehatan bisnis & $\begin{array}{l}\text { Tidak mampu menjaga kesehatan } \\
\text { bisnis }\end{array}$ \\
\hline Mempunyai rencana bisnis dan target yang jelas & $\begin{array}{l}\text { Tidak mempunyai rencana dan } \\
\text { target, ingin hasil instan }\end{array}$ \\
\hline Membangun dan mengembangkan networking & Berjalan apa adanya \\
\hline Fokus pada bidang yang dikuasai & $\begin{array}{l}\text { Tidak fokus pada satu bidang untuk } \\
\text { di tekuni }\end{array}$ \\
\hline $\begin{array}{l}\text { Bermental kuat dan tetap yakin dengan } \\
\text { kemampuan yang dimiliki }\end{array}$ & Gampang terpengaruh orang lain \\
\hline
\end{tabular}

Sumber: Apriansyah, et al., (2020)

Tujuan penting yang ingin dicapai dari dilakukannya program Pengabdian Kepada Masyarakat ini ialah mampu meningkatkan semangat, Meningkatkan Pengetahuan Penjualan Online dan mampu inovasi produk baru untuk peningkatan perekonomian kelompok "Mujur Fish Farm".

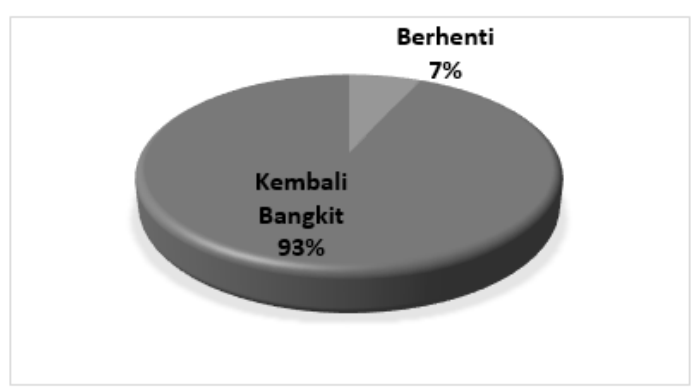

Gambar 7. Hasil Post-Test Semangat Setelah Pemberian Materi

Dari hasil gambar diatas, setelah pemberian materi hasil post test akhir penyuluhan menunjukkan bahwa 93\% anggota kelompok "Mujur Fish Farm" memahami materi yang disampaikan dan dapat meningkatkan pola pikir dan semangat untuk mebali bangkit membangun bisnis budidaya ikan tawar, dengan melakukan inovasi produk dan penjualan online. Anggota kelompok juga sudah memahami langkah-langka yang perlu dilakukan untuk menghadapi pandemi Covid-19 agar pendapatan terus ada. Pengetahuan ini dapat dijadikan bekal untuk membuka dan mengembangakan ide-ide bisnis baru sesuai kebutuhan konsumen dimasa Covid-19 ini. 
Peningkatan keinginan untuk jualan Online/E-Commerce

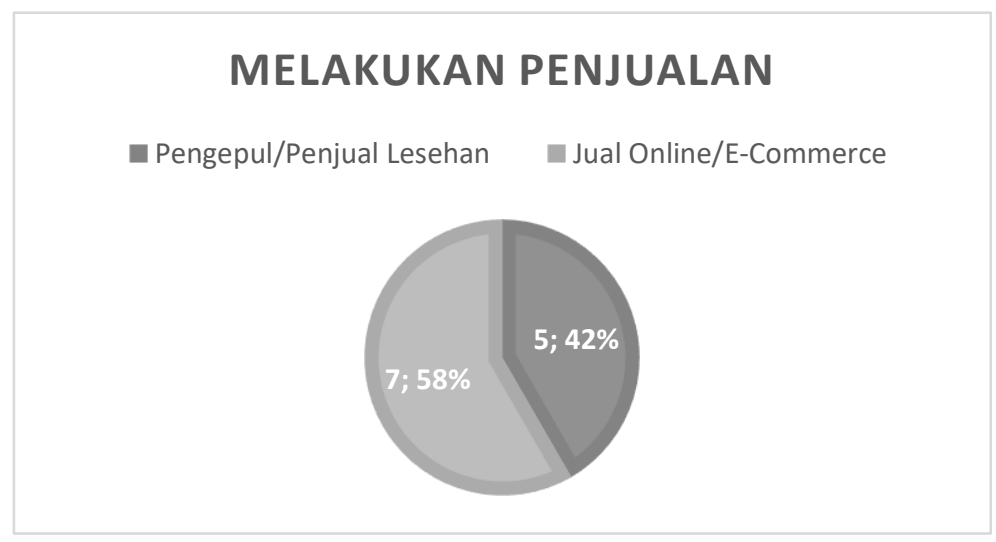

Gambar 8. Hasil Post-Test Melakukan Penjualan Online

Dari gambar diatas menunjukkan ada peningkatan yang signifikan pada anggota kelompok "Mujur Fish Farm" untuk beralih dalam melakukan penjulan secara online dimasa pandemi Covid-19 ini, baik untuk lebih intens lagi melakukan penawaran melalui aplikasi WhattsApp, Facebook, Instagram ataupun melalui aplikasi E-Commerce. Berdasarkan hasil jawaban diatas, sebelum penyampaian materi sebesar 14,93 melakukan penjualan ke tengkulak, atau secara langsung dijual pelaku usaha rumah makan dan penjual pecel lele sedangkan hanya $1,7 \%$ yang sudah melakukan online lewat WA yaitu ketua kelompok. Akan tetapi, setelah pemberian materi ada perubahan dimana sebesar 7,58\% anggota kelompok ingin mencoba melakukan penjualan secara online, sedangkan 5,42\% masih tetap ingin melakukannya secara langsung ke pengepul atau rumah makan. Alasannya belum memiliki smartphone, dan juga masih belum terbiasa melakukan penjualan online, lebih enak ketemu langsung.

Melakukan inovasi produk

Adapun bukti nyata yang sudah dilakukan anggota kelompok "Mujur Fish Farm" saat ini ialah inovasi produk dengan mengubah ikan menjadi Dimsum. Dimsum olahan makanan yang berasal dari Cina memiliki cita rasa nikmat dengan tekstur lembut yang memanjakan lidah, olahan makanan ini lagi banyak digemari oleh kalangan muda di Indonesia. Adapun hasil inovasi produk anggota kelompok "Mujur Fish Farm" dengan mengolah ikan menjadi Dimsum berbahan ikan yang sudah dijalankan dan dilakukan penjualan secara online.

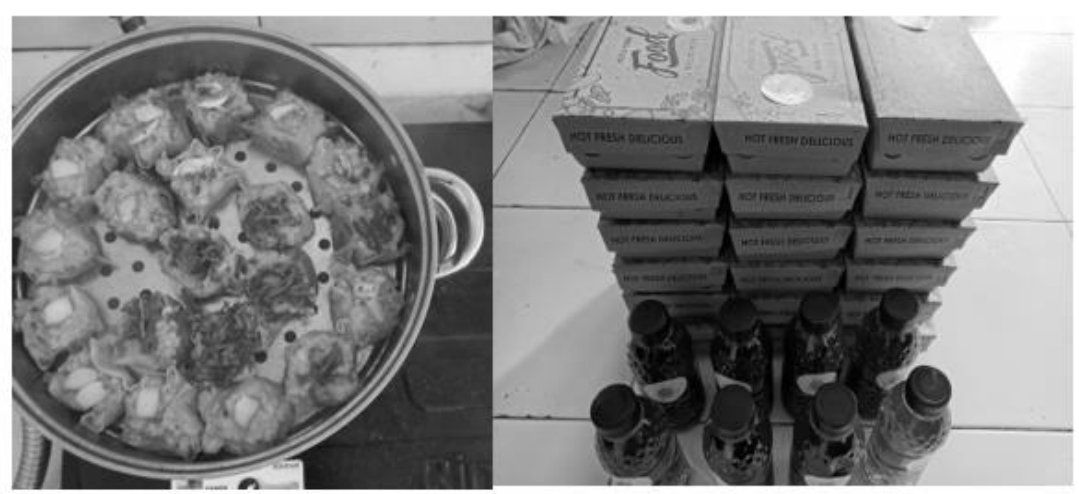

Gambar 9. Hasil Olahan Dimsum Berbahan Ikan 
Dari hasil gambar diatas membuktikan dimana dari Pengabdian Kepada Masyarakat yang sudah dilakukan memberikan sipirt dan pola piker baru kepada anggota kelompok "Mujur Fish Farm" untuk melakukan inovasi produk dimasa pandemi covid-19 ini. Hasil penjualan produk ini sudah dilakukan secara online lewat media social lewat WhattsApp dan Instagram.
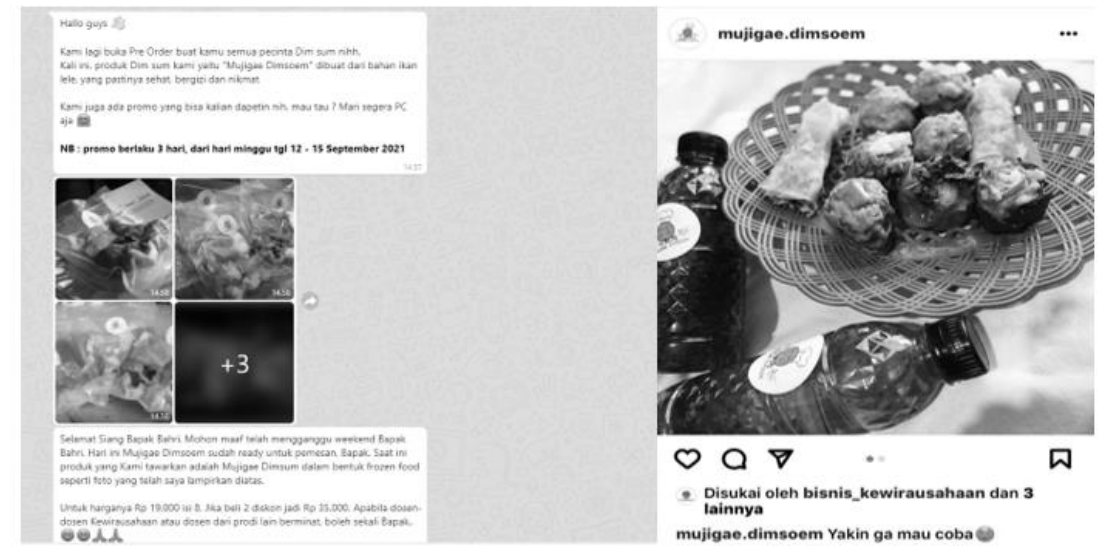

Gambar 10. Penjualan melalui media sosial WhattsApp dan Instagram

Dari gambar diatas meunjukkan anggota kelompok sudah melakukan penjualan produk Dimsum berbahan baku ikan, yang dikombinasikan dengan minuman sehat berbahan baku alami. Pemesanan produk bias melalui pesan WA dan Instagram, dan proses pengiriman melalui Kantor Pos dan pesan antar secara langsung (COD).

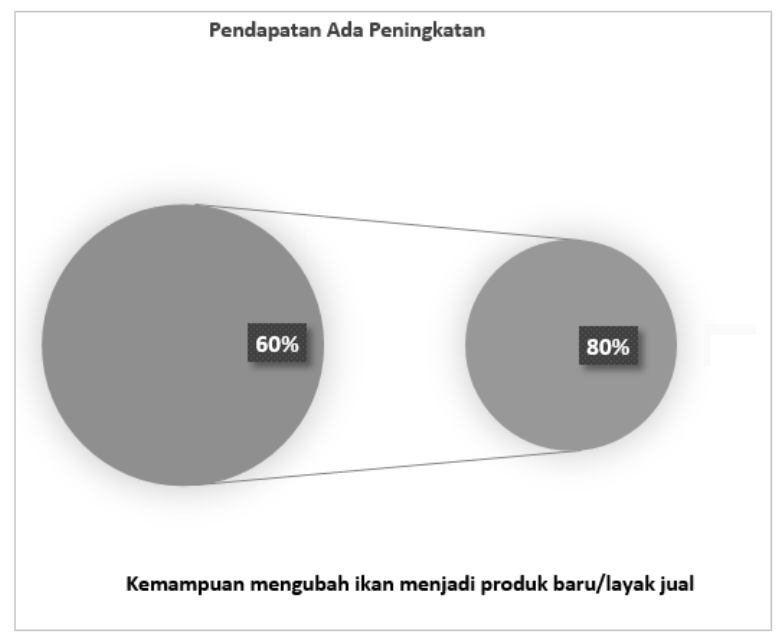

Gambar 11. Hasil Post-Test Peningkatan Pendapatan dan Kemampuan dalam Mengolah Ikan

Dari gambar diatas, setelah dilakukannya kegiatan Pengabdian Kepada Masyarakat pada anggota kelompok "Mujur Fish Farm" dihasilkan sudah ada peningkatan penghasilan dari anggota kelompok yang awalnya hasil Pre-Test $100 \%$ anggota kelompok menyampaikan penurunan pendapatan. Namun dari hasil informasi yang tim dapatkan, setelah kegiatan PkM dilakukan, selanjutnya anggota kelompok mempunyai inspirasi untuk melakukan inovasi produk untuk mengubah ikan menjadi produk Dimsum. Hasilnya dimasa pandemi ini anggota kelompok "Mujur Fish Farm" sudah melakukan penjualan produk Dimsum yang juga berdampak pada peningkatan pereknomian, karena berdasarkan informasi yang saya dapatkan dimana hampir setiap hari produk Dimsum ini ada pesanan dari pelanggan. Namun pendapatan belum $100 \%$ masih di angka $60 \%$, disebabkan inovasi yang dilakukan baru berupa produk 
Dimsum dan minuman kesehatan. Sehingga inovasi produk baru berjalan $80 \%$. Kedepannya akan membuat produk kerupuk dan cemilan kripik berbahan ikan. Namun saat ini juga, ide usaha baru yang dilakukan anggota kelompok, membuka kolam pemancingan berbayar. Hal ini membuktikan anggota kelompok 'Mujur Fish Farm' memiliki kecerdasan emosional yang mampu memecahkan masalah, mampu bertahan dimasa Covid-19, mampu bertahan dari kegagalan. Tidak takut gagal, tidak mudah menyerah (berhenti).

\section{KESIMPULAN}

Kegiatan pengabdian kepada masyarakat ini dilakukan dengan memaparkan materi, diskusi dan pemberian pre-test dan post-test kemampuan dalam memahami materi yang disampaikan. Materi utama yang diberikan dalam penyuluhan terkait mindset and spirit entrepreneur dalam berwirausaha dimasa pandemi Covid-19. Selanjutnya inovasi produk dan strategi penjualan online yang harus dilakukan anggota kelompok "Mujur Fish Farm" agar produk bisa terjual dan dampaknya dapat meningkatkan perekonomian anggota. Penyuluhan dilakukan pada anggota Kelompok Budidaya Ikan Tawar "Mujur Fish Farm" di Dusun Brengosan Brengosan Desa Donoharjo, Kecamatan Nganglik, Kabupaten Sleman, Kota Yogyakarta. Kegiatan Pengabdian Kepada Masyarakat berhasil dilakukan karena adanya peningkatan semangat (spirit) dan pola pikir (mindset) anggota kelompok untuk kembali bangkit membangun usaha budi daua ikan nya. Hasil post test akhir menunjukkan peningkatan $93 \%$ dibandingkan dengan presentase awal mindset and spirit anggota kelompok untuk bangkit berwirausaha dimasa Covid-19 ini hanya 60\%, kebanyakan anggota kelomok mau berhenti membudidayakan ikan karena pendapatan menurun sehingga mau berpindah pada pekerjaan lain. Anggota kelompok juga telah mengerti pentingnya melakukan penjualan secara online melalui aplikasi WhattsApp, Facebook, Instagram ataupun melalui aplikasi E-Commerce terbukti setelah pemberian materi ada perubahan dimana sebesar 7,58\% anggota kelompok ingin mencoba melakukan penjualan secara online, sedangkan sebelumnya hanya $1,7 \%$. Perubahan terbesar dari kegiatan ini anggota kelompok berhasil melakukan inovasi produk baru dengan membuat produk makanan Dimsum yang berbahan ikan, yang dikombinasikan dengan minuman sehat berbahan baku alami. Dari hasil inovasi produk ini berdampak pada peningkatan pendapatan sebesar $60 \%$ yang awalnya tidak ada penjualan dan pendapatan sama sekali. Selain itu saat ini anggota "MUJUR FISH FARM". Sudah membuka usaha baru yaitu kolam pemancingan berbayar, yang sebelum PkM belum terpikirkan untuk dilakukan. Keberanian untuk mengubah pola pikir anggota kelompok ini merupakan suatu awal yang baik, hingga kedepan terus berinovasi dan mengembangkan usahanya tersebut, agar dapat menjadi solusi dalam meningkatkan pendapatan perekonomian seluruh anggota kelompok "MUJUR FISH FARM".

\section{UCAPAN TERIMA KASIH}

Terima kasih kami ucapkan kepada LPPM Universitas Widya Mataram (UWM) atas dukungan pendanaan sehingga kegiatan pengabdian ini terlaksana. Terima kasih kepada Dekan Fakultas Ekonomi yang telah memberikan dukungan dana dan ijin kepada kami. Terima kasih juga kami ucapkan kepada Bapak Kepala Dukuh Dusun Brengosan yang telah memberikan izin kepada kami untuk melakukan pengabdian ini. Secara khusus kami ucapkan terima kasih kepada Ketua Kelompok beserta anggota "Mujur Fish Farm" yang telah memfasilitasi kegiatan ini sehingga dapat berjalan dengan lancar. Serta dari kegiatan ini bisa terjalin kerjasama antara Program Studi Kewirausahaan Univsesitas Widya Mataram dengan 
Kelompok "Mujur Fish Farm", semoga kerjasama ini menghasilkan manfaat untuk anggota kelompok dan Prodi Kewirausahaan.

\section{Daftar Pustaka}

1. Apriansyah, M, Sahroni, S, Sutoro, Mukrodi, M., \& Krisyanto. (2020). Membangun Spirit Kewirausahaan Sebagai Langkah Positif Di Masa Pandemi Pada Kelompok PKK Kel. Cipinang Melayu. Abdi Laksana, 1(3), 418-423. https://doi.org/10.32493/al-jpkm.v1i3.6880

2. Dewi, L. R. (2018). Mindset dan Perilaku Kewirausahaan Wanita Pengusaha Jasa Boga di Yogyakarta.

3. Dweck, C. S. (2006). Mindset: The New Psychology of Success. Random House, Inc.

4. Euis, R. Y. \& K. (2010). Strategi Pengembangan Kreativitas Pada Anak Usia Taman KanakKanak. Kencana.

5. Fitra, S. (2021, Juli 31). Kasus Covid-19 Bertambah 38.679 Kasus. https://databoks.katadata.co.id/datapublish/2021/07/25/kasus-covid-19-bertambah-38679-kasusminggu-257.

6. Gunawan, A. W. (2007). Genius Learning Strategi. Gramedia Pustaka Utama.

7. Hendro. (2011). Dasar-Dasar Kewirusahaan. In Erlangga.

8. Latief, J. (2017). Kewirausahaan Kiat Sukses Menjadi Wirausaha. Dinas Pendidikan Nasional Jakarta.

9. Lewenussa, R., \& Suaidy, H. (2019). Pengaruh Pola Pikir (Mindset) Kewirausahaan Terhadap Motivasi Dan Keterampilan Wirausaha Mahasiswa Program Studi Manajemen Universitas Muhammadiyah Sorong. SENTRALISASI. https://doi.org/10.33506/sl.v8i1.385

10. Maria E, Suharyadi S, \& Hudiono, R. (2021). Implementasi pemasaran digital berbasis website sebagai strategi kenormalan baru Dusun Srumbung Gunung pasca Covid-19. Riau Journal of Empowerment, 4(1), 1-10. https://doi.org/10.31258/raje.4.1.1-10

11. Neneh, N. B. (2012). An exploratory study on entrepreneurial mindset in the small and medium enterprise (SME) sector: A South African perspective on fostering small and medium enterprise (SME) success. African Journal of Business Management, 6(9). https://doi.org/10.5897/ajbm10.1631

12. Purwaningsih, E. (2015). Pengaruh Spirit Kewirausahaan dan Pengalaman Praktik Kerja Industri Terhadap Minat Berwirausaha Siswa Kelas XII. Jurnal Pendidikan Dan Pembelajaran Khatulistiwa, 4(8), 1-14. https://jurnal.untan.ac.id/index.php/jpdpb/article/view/11157

13. Subargah, L. (2021, Juli 31). Seluruh Objek Wisata Sleman Ditutup. Jogjapolitan. https://jogjapolitan.harianjogja.com/read/2021/07/03/512/1076065/seluruh-objek-wisata-slemanditutup

14. Tambajong, H. O. H. (2015). Strategi Pendekatan Participatory Rural Appraisal (PRA) Dalam Mewujudkan Kemandirian Masyarakat Transmigrasi Di Kampung Marga Mulia Distrik Semangga. Societas: Jurnal Ilmu Administrasi Dan Sosial, 4(2), 114-131. https://doi.org/https://doi.org/10.35724/sjias.v4i2.437

15. Wirawan. (2021). Ketenagakerjaan Dalam Data Jilid 3 Jakarta Selatan: Pusat Data dan Informasi Ketenagakerjaan. 